\title{
Age- and Sex-Specific Fear Conditioning Deficits in Mice Lacking Pcdh10, an Autism Associated Gene
}

\author{
Sarah L. Ferri ${ }^{1}$, Holly C. Dow ${ }^{2},{\text { Hannah } \text { Schoch }^{3}, \text { Ji Youn Lee }}^{1}$, Edward S. Brodkin ${ }^{2}$, Ted Abel ${ }^{1}$ \\ ${ }^{1}$ Iowa Neuroscience Institute, Department of Neuroscience and Pharmacology, University of \\ Iowa, 169 Newton Road, 2312 Pappajohn Biomedical Discovery Building, Iowa City, IA 52242, \\ USA \\ ${ }^{2}$ Department of Psychiatry, Perelman School of Medicine at the University of Pennsylvania, \\ Translational Research Laboratory, 125 South $31^{\text {st }}$ Street, Room 2202, Philadelphia, PA 19104- \\ 3403, USA \\ ${ }^{3}$ Department of Biomedical Sciences, Elson S. Floyd College of Medicine, Washington State \\ University, 412 E. Spokane Falls Blvd., Spokane, WA, 99202, USA
}

Correspondence:

Ted Abel

169 Newton Road

2312 Pappajohn Biomedical Discovery Building

Iowa City, IA 52242

ted-abel@uiowa.edu

$319353-4534$ 


\begin{abstract}
PCDH1O is a gene associated with Autism Spectrum Disorder. It is involved in the growth of thalamocortical projections and dendritic spine elimination. Previously, we characterized mice Pcdh10 haploinsufficient mice ( $P c d h 10^{+/-}$mice) and found male-specific social deficits that are rescued by $\mathrm{N}$ methyl-D-aspartate receptor (NMDAR) partial agonist $d$-cycloserine, increased ultrasonic vocalizations in pups, and dark phase hypoactivity. In addition, we determined that the basolateral amygdala (BLA) of these mice exhibited increased dendritic spine density of immature morphology, decreased NMDAR expression, and decreased gamma synchronization. Here, we further characterize $P c d h 10^{+/-}$mice by testing for fear memory, which relies upon BLA function. We used both male and female $P c d h 10^{+/-}$mice and their wild-type littermates at two ages, juvenile and adult, and in two learning paradigms, cued and contextual fear conditioning. We found that males at both ages and in both assays exhibited fear conditioning deficits, but females were only impaired as adults in the cued condition. These data are further evidence for male-specific alterations in BLA-related behaviors in $P c d h 10^{+/-}$mice, and suggest that these mice may be a useful model for dissecting male specific brain and behavioral phenotypes relevant to social and emotional behaviors.
\end{abstract}

Keywords: autism, ASD, fear conditioning, sex differences, protocadherin 


\section{Introduction}

Protocadherin 10 (Pcdh10) is a calcium-dependent transmembrane cell adhesion molecule belonging to the $\delta 2$ subfamily of nonclustered protocadherins in the cadherin superfamily (Hirano et al., 1999; Nakao et al., 2008; Kim et al., 2011). PCDH10 (OL-protocadherin) is located on chromosome 4 in humans and chromosome 3 in mice and is expressed almost exclusively in the mammalian brain, particularly in the striatum, amygdala, and cerebellum (Hirano et al., 1999; Aoki et al., 2003; Kim et al., 2011). Pcdh10 has been associated with cell migration (Nakao et al., 2008), thalamocortical and corticothalamic projections (Uemura et al., 2007), and proteasomal degradation of PDS-95 to promote synapse elimination (Tsai et al., 2012).

Genome-wide analyses and loci mapping have revealed copy number variations in the $P C D H 10$ gene and its regulatory region in association with Autism Spectrum Disorder (ASD), a neurodevelopmental disorder that causes deficits in communication and social interaction and repetitive or restricted behaviors (Morrow et al., 2008; Bucan et al., 2009; Taylor et al., 2020). Because ASD has been linked to a large number of genes encoding synaptic cell adhesion molecules, many transgenic mouse models have been created, including a Pcdh10 knockout model in which the first exon was replaced with a lacZ-neo selection cassette (Uemura et al., 2007; Taylor et al., 2020).

Because mice homozygous for Pcdh10 deletion do not survive past 3-4 weeks of age, likely due to failure of striatal axon outgrowth, we recently characterized heterozygous mice (Pcdh10 ${ }^{+/}$) (Uemura et al., 2007). We found that male and female $P c d h 10^{+/-}$pups at postnatal day 6 emitted increased maternal separation-induced ultrasonic vocalizations compared to their WT littermates. We also uncovered a male-specific deficit in juvenile social approach behavior that is rescued with systemic administration of $\mathrm{d}$-cycloserine, a partial NMDAR agonist at the glycine site. In addition, we demonstrated that these mice have no evidence of anxiety-like behavior in elevated zero maze and intact olfactory habituationdishabituation despite strong Pcdh10 expression in the olfactory bulb. Female mutants had decreased motor performance in rotarod compared to their wild-type littermates. Pcdh10 $10^{+-}$mice did not exhibit any deficits in novel object recognition task and no repetitive behaviors were observed (Schoch et al., 2017). Males, but not females demonstrated hypoactivity in long-term home-cage activity monitoring specifically in the dark phase (Angelakos et al., 2019). Interestingly, Pcdh10 $10^{+/-}$males had a number of changes in structure and function of the basolateral amygdala (BLA). Using voltage sensitive dye, we

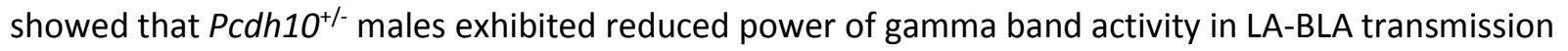
compared to WT littermates, indicating reduced connectivity between these areas. In addition, $P c d h 10^{+/-}$ males exhibited increased spine density of immature morphology (filopodial spines) on LA/BLA pyramidal neurons and decreased expression of GluN1A and GluN2A NMDAR subunits in the postsynaptic fraction of BLA cells compared to those of WT littermates (Schoch et al., 2017).

Pcdh $10^{+/-}$males are known to have abnormalities in the BLA and deficits in social behaviors that engage the BLA (Ferri et al., 2015; Schoch et al., 2017). This raises the question of whether Pcdh10+/- males might have deficits in fear conditioning, a behavior that involves the BLA (Ressler and Maren, 2019), and that is disrupted in several in mouse models relevant to ASD (Han et al., 2012; Banerjee et al., 2016; Kim et al., 2016), and in autistic humans (Gaigg and Bowler, 2007; Top Jr. et al., 2016). We hypothesized that fear conditioning would be disrupted in $P c d h 10^{+/-}$mice, and we tested juvenile and adult male and female Pcdh10 $10^{+-}$and WT littermate mice in both contextual and cued fear conditioning paradigms. 


\section{Materials and Methods}

\subsection{Animals}

$P c d h 10^{+/-}$males were produced by Lexicon Pharmaceuticals, Inc. (Uemura et al., 2007). The first exon of Pcdh10 was replaced with a lacZ-neo selection cassette. Founders were backcrossed with C57BL/6J females for more than 15 generations. Mice were bred and experiments took place both at University of lowa and University of Pennsylvania. In both cases, $P c d h 10^{+/-}$males were crossed with $\mathrm{C} 57 \mathrm{BL} / 6 \mathrm{~J}$ females to produce heterozygous Pcdh10+/- and wild-type offspring, which were housed with same-sex littermates 2-5 per cage in a temperature- and humidity-controlled environment on a 12-hour light/dark cycle. All mice had access to food and water ad libitum. Behavior was conducted during the light cycle. All mice were cared for in accordance with the National Institutes of Health Guide for the Care and Use of Laboratory Animals and all procedures were approved by the Institutional Animal Care and Use Committees at University of lowa and University of Pennsylvania.

\subsection{Cued Fear Conditioning}

Five to seven days prior to training, mice were habituated to single housing. Mice were handled for 2-3 min per day for 3-5 days prior to conditioning. On the day of training, each mouse was placed in a chamber with electrified grid flor inside a sound attenuating box (Med Associates, Inc.) for 3 min. After 2 min of free exploration, a tone $(2900 \mathrm{~Hz}, 70 \mathrm{~dB})$ sounded, which lasted $30 \mathrm{~s}$ and co-terminated with a 2 $\mathrm{s}, 1.5 \mathrm{~mA}$ shock, and the mouse was removed $30 \mathrm{~s}$ after that. Twenty-four hours later, a test session was conducted. The mice were placed in the same training chamber which had been significantly altered into a novel context for $6 \mathrm{~min}$. White plastic inserts covered the electrified grid floor and the walls of the chamber had been altered to change the texture and shape of the compartment from a cube to a cylinder. Several drops of lemon dish soap were placed within the chamber to alter the smell. Freezing behavior was measured continuously by FreezeScan software (CleverSys Inc.).

\subsection{Contextual Fear Conditioning}

Mice were handled and housed as described above. On training day, individual mice were placed in the training chamber described above for 3 minutes. The first 2:28 of free exploration were considered "Baseline," after which a single $1.5 \mathrm{~mA}$ footshock was delivered, lasting $2 \mathrm{~s}$. The mice then remained in the chamber for an additional $30 \mathrm{~s}$. Twenty-four hours later (test session) the mice were placed in the same, unaltered chamber for 5 min. Freezing behavior was measured continuously by FreezeScan software (CleverSys Inc.).

\subsection{Statistics}

For all graphs, repeated measures two-way ANOVAs were used to determine main effects of session (training versus testing), genotype ( $P c d h 10^{+/-}$vs wild-type), and an interaction. Bonferroni was used as a post hoc test. Significance was set to $p<0.05$.

\section{Results}

\subsection{Cued Fear Conditioning}


In juvenile male mice undergoing cued fear conditioning (28-32 d), a RM two-way ANOVA revealed a main effect of session (training, Pr-CS and during CS at $24 \mathrm{hr}$ test; $F_{(2,50)}=38.620, p<0.0001$ ), no main effect of genotype $\left(P c d h 10^{+/-}\right.$vs wild-type; $\left.F_{(1,25)}=0.529, p=0.474\right)$, and a significant genotype $x$ session interaction $\left(\mathrm{F}_{(2,50)}=6.176, \mathrm{p}=0.004\right)$. A Bonferroni post hoc test indicated that $P c d h 10^{+/-}$males spent a similar percentage of time freezing compared to their wild-type littermates during the baseline period of training ( $p>0.999)$, and during the Pre-CS period of the $24 \mathrm{~h}$ test, prior to the presentation of the tone in the altered context $(p=0.326)$. However, during the presentation of the tone (CS) during the $24 \mathrm{~h}$ test, $P c d h 10^{+/-}$males spent significantly less time freezing than their WT littermates $(p=0.048$; Fig. 1A). For juvenile females (28-32 d), a RM two-way ANOVA revealed no main effects of session $\left(F_{(2,52)}=59.940\right.$, $p<0.0001)$ or genotype $\left(F_{(1,26)}=0.005, p=0.942\right)$, and no genotype $x$ session interaction $\left(F_{(2,52)}=0.004\right.$, $\mathrm{p}=0.996)$. Bonferroni post hoc analysis showed that $P c d h 10^{+/-}$females spent a similar percentage of time freezing compared to their wild-type littermates during all sessions (Baseline, Pre-CS, and CS; $p>0.999$ for each; Fig. 1B).

For adult male mice (80-100 d), a RM two-way ANOVA revealed a main effect of session $\left(F_{(2,60)}=40.410\right.$, $p<0.0001)$, a main effect of genotype $\left(F_{(1,30)}=5.516, p=0.026\right)$, and a significant genotype $x$ session interaction $\left(\mathrm{F}_{(2,60)}=8.315, \mathrm{p}=0.0006\right)$. A Bonferroni post hoc analysis demonstrated that $P c d h 10^{+/}$males spent a similar percentage of time freezing compared to their wild-type littermates during the baseline period of training $(\mathrm{p}>0.999)$. $P c d h 10^{+-}$males seemed to freeze less than WT during the Pre-CS period of the $24 \mathrm{~h}$ test, however the difference was not significant ( $\mathrm{p}=0.093$ ). Pcdh10+/- males spent significantly less time freezing during the CS tone during the $24 \mathrm{~h}$ test compared to WT littermates ( $p=0.0007$; Fig. 1C). Freezing behavior of adult females (80-100 d) in cued fear conditioning was analyzed using a RM two-way ANOVA. Results indicated a main effect of session $\left(F_{(2,70)}=39.670, p<0.0001\right)$, no main effect of genotype $\left(F_{(1,35)}=2.011, p=0.165\right)$, and a significant genotype $x$ session interaction $\left(F_{(2,70)}=6.683, p=0.002\right)$. A Bonferroni post hoc test showed that $P c d h 10^{+/-}$females spent a similar percentage of time freezing compared to their wild-type littermates during the baseline period of training $(p=0.952)$ and during the Pre-CS period of the $24 \mathrm{~h}$ test $(\mathrm{p}=0.570)$. However, during the presentation of the tone (CS) during the $24 \mathrm{~h}$ test, they spent significantly less time freezing than their WT littermates ( $p=0.011$; Fig. 1D).

In summary, both juvenile and adult $P c d h 10^{+/-}$males exhibit deficits in cued fear conditioning compared to their wildtype littermates, while adult, but not juvenile, female $P c d h 10^{+/-}$mice show an impairment in cued fear conditioning. 

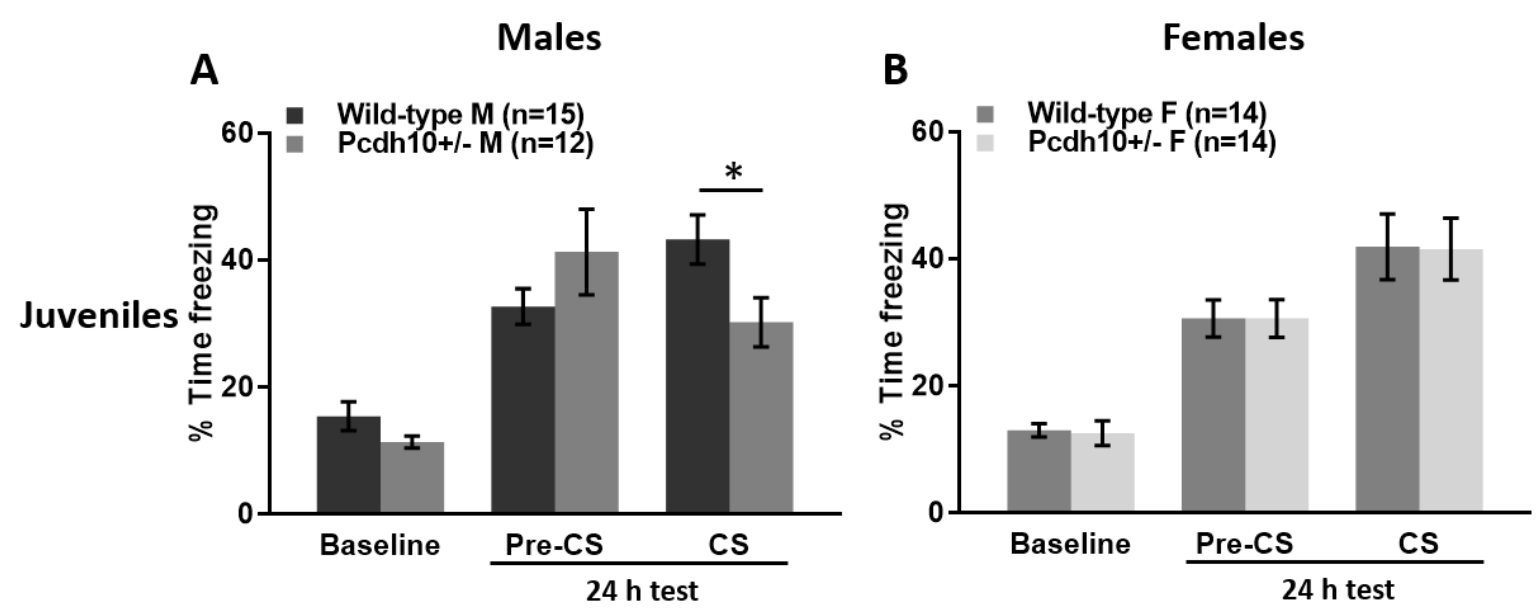

C
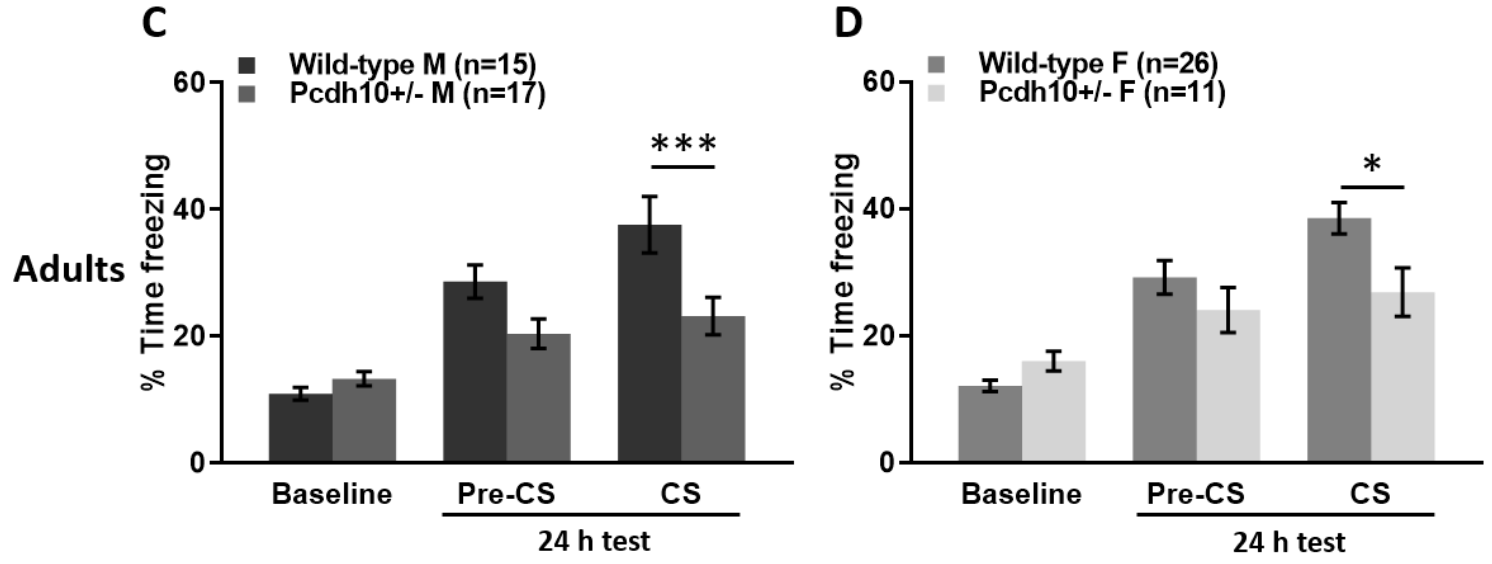

Figure 1. Juvenile and adult males and adult females lacking one copy of $P c d h 10$ exhibit cued fear conditioning deficits. A) Juvenile $P c d h 10^{+/-}$males spent a similar percentage of time freezing as their wild-type littermates during a baseline period of training and in the pre-CS period, prior to the tone cue during the $24 \mathrm{hr}$ test. During the presentation of the tone cue, however, $P c d h 10^{+/-}$males froze less than WT. B) Juvenile $P c d h 10^{+/-}$females froze for a similar percentage of time as their wild-type littermates during the baseline period of training and the Pre-CS and CS periods of the $24 \mathrm{~h}$ cued fear conditioning test. C) Adult $P c d h 10^{+/-}$males spent significantly less time freezing to a tone cue $24 \mathrm{~h}$ after training than their WT littermates. Freezing levels were not significantly different during baseline. D) $P c d h 10^{+/-}$adult females had similar freezing behavior during a baseline period of training and $24 \mathrm{~h}$ later in the Pre-CS period of the cued fear conditioning test. During the CS presentation of the $24 \mathrm{~h}$ test, $P c d h 10^{+/-}$females froze less than their wild-type littermates. $* * *=p<0.001, *=p<0.05$.

\subsection{Contextual Fear Conditioning}

In juvenile male mice (28-32 d) trained with a single shock and tested in the same context, a RM twoway ANOVA revealed a main effect of session (training vs test; $F_{(1,24)}=82.010, p<0.0001$ ), a trend towards a main effect of genotype $\left(P c d h 10^{+/-}\right.$vs wild-type; $\left.F_{(1,24)}=3.570, p=0.071\right)$, and a significant genotype $x$ session interaction $\left(\mathrm{F}_{(1,24)}=5.416, \mathrm{p}=0.029\right)$. A Bonferroni post hoc test showed that $P c d h 10^{+/}$males spent a similar percentage of time freezing compared to their wild-type littermates during the baseline period of training ( $p>0.999$ ), but significantly less during the $24 \mathrm{~h}$ test ( $p=0.009 ;$ Fig. $2 \mathrm{~A}$ ). For juvenile female mice (28-32 d) undergoing contextual fear conditioning, a RM two-way ANOVA revealed a main effect of 
session $\left(F_{(1,20)}=58.570, p<0.0001\right)$, and no main effect of genotype $\left(F_{(1,20)}=1.375, p=0.255\right)$ and no significant genotype $x$ session interaction $\left(F_{(1,20)}=3.393 p=0.080\right)$. A Bonferroni post hoc test indicated that $P c d h 10^{+/-}$females spent a similar percentage of time freezing compared to their wild-type littermates during the baseline period of training ( $p>0.999)$. $P c d h 10^{+/-}$females seemed to spend less time freezing during the $24 \mathrm{~h}$ test, but this difference did not reach statistical significance $(p=0.081$; Fig. 2B).

For contextually-conditioned adult male mice (80-180 d) receiving a single shock during training and tested in the same context $24 \mathrm{~h}$ later, a RM two-way ANOVA revealed a main effect of session (training vs test; $\left.F_{(1,31)}=207.300, p<0.0001\right)$, a main effect of genotype $\left(P c d h 10^{+/}\right.$vs wild-type; $F_{(1,31)}=9.329$, $p=0.005)$, and a significant genotype $x$ session interaction $\left(F_{(1,31)}=6.249, p=0.018\right)$. A Bonferroni post hoc test demonstrated that $P c d h 10^{+/-}$males spent a similar percentage of time freezing compared to their wild-type littermates during the baseline period of training $(p=0.401)$, but significantly less during the 24 $h$ test ( $p=0.0005 ;$ Fig. $2 C$ ). For adult female mice (80-180 d) undergoing contextual fear conditioning, a RM two-way ANOVA revealed a main effect of session $\left(F_{(1,37)}=99.150, p<0.0001\right)$, no main effect of genotype $\left(F_{(1,37)}=0.174, p=0.679\right)$, and no genotype $x$ session interaction $\left(F_{(1,37)}=0.967, p=0.332\right)$. $A$ Bonferroni post hoc test showed that $P c d h 10^{+/-}$females spent a similar percentage of time freezing compared to their wild-type littermates during the baseline period of training $(p>0.999)$ and during the $24 \mathrm{~h}$ test ( $p=0.709 ;$ Fig. 2D).

In summary, both juvenile and adult $P c d h 10^{+/-}$males demonstrate contextual fear conditioning deficits compared to their wildtype littermates, while $P c d h 10^{+/-}$females at both ages are unaffected. 

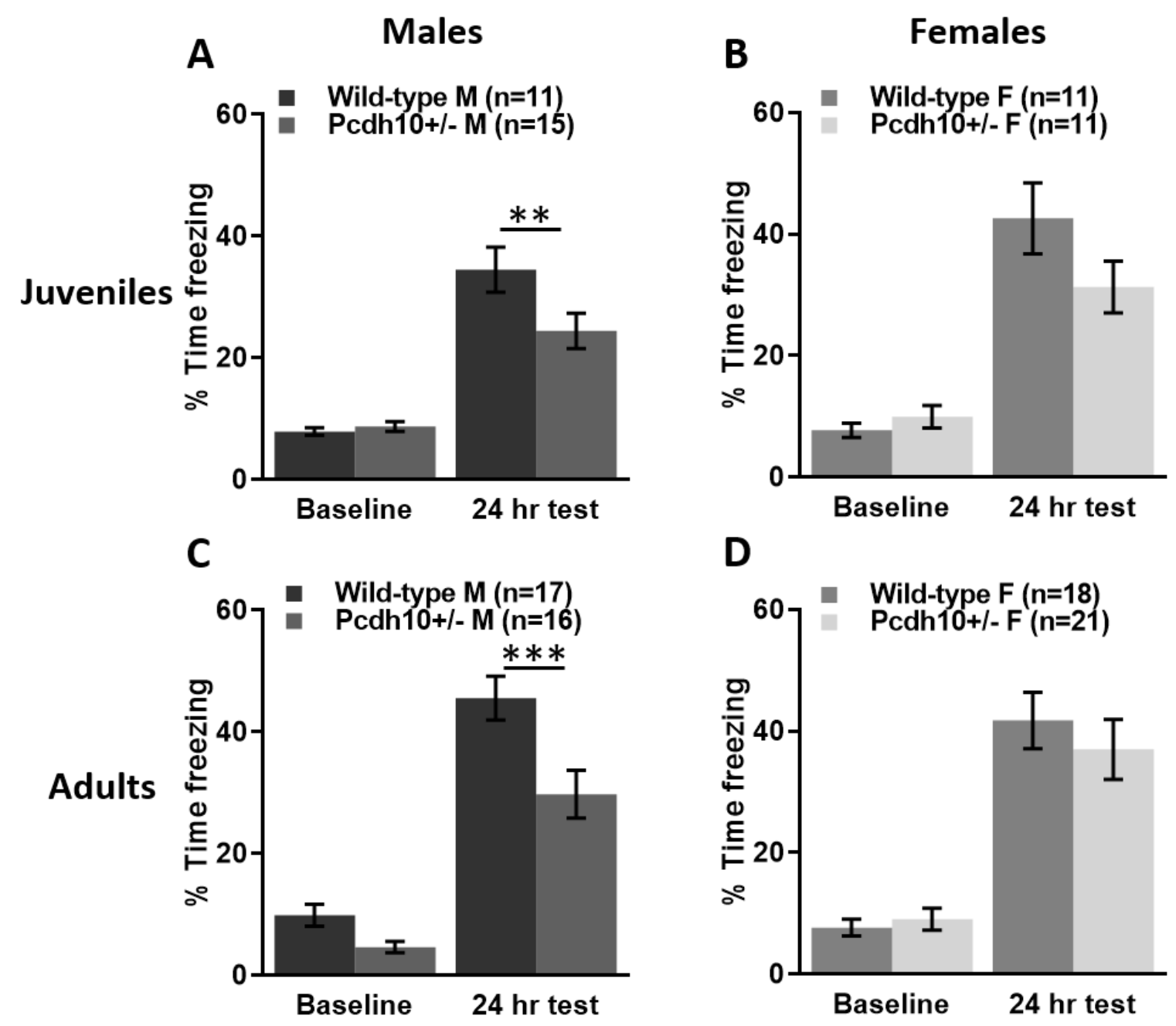

Figure 2. Juvenile and adult males lacking one copy of $P c d h 10$ exhibit contextual fear conditioning deficits. A) Juvenile $P c d h 10^{+/-}$males spent significantly less time freezing 24 hours after a single-shock contextual fear conditioning training than their wild-type littermates. Baseline freezing prior to the shock was similar between groups. B) Juvenile female $P c d h 10^{+/}$mice seemed to freeze less than wildtype littermates in a long-term memory test of contextual fear conditioning, but this difference was not statistically significant. Baseline freezing was similar between the groups. C) Adult $P c d h 10^{+/}$and WT littermate males spent a similar percentage of time freezing during the baseline period of contextual fear conditioning but $P c d h 10^{+/-}$males spent significantly less time freezing $24 \mathrm{~h}$ later. D) Adult $P c d h 10^{+/-}$ females had similar freezing behavior compared to their wild-type littermates, both at baseline and at the 24 h test. $* * *=p<0.001,{ }^{* *}=p<0.01$.

\section{Discussion}

Fear conditioning has been strongly associated with BLA function. BLA lesions disrupt both cued and contextual fear conditioning (LeDoux et al., 1990; Goosens and Maren, 2001). Contextual fear conditioning also involves the hippocampus, particularly the dorsal portion and CA3 (Clark and Squire, 1998). We have previously characterized several abnormalities in the LA/BLA of Pcdh $10^{+/-}$males, 
including an increase in density of filopodial dendritic spines (Schoch et al., 2017). These spines are immature and likely have decreased synaptic functioning (Harris, 1999) and may prevent the plasticity necessary for fear conditioning (Rogan et al., 1997; Nabavi et al., 2014). In addition, we showed decreased gamma synchronization in the LA-BLA circuit (Schoch et al., 2017). Gamma oscillations are known to be important for fear memory retrieval and can modulate BLA neuronal firing (Popescu et al., 2009; Stujenske et al., 2014; Bocchio et al., 2017). Finally, we demonstrated a decrease in NMDAR expression in the BLA of $P c d h 10^{+/-}$males (Schoch et al., 2017). NMDAR function is important for fear memory; it has been shown that NMDAR antagonist infusion into the BLA blocked fear conditioning acquisition (Campeau et al., 1992). While hippocampus of $P c d h 10^{+/-}$mice has not been thoroughly investigated, behavior in another hippocampus-dependent task, the Morris water maze, is intact in these mice (unpublished). Further investigation of the role of the hippocampus will be important.

There are other important players in fear memory learning as well, including BLA GABAergic interneurons (Bocchio et al., 2017). Neurotransmitters such as dopamine, noradrenaline, and acetylcholine are also important (de la Mora et al., 2010; Heath et al., 2015; Kwon et al., 2015; de Oliveira et al., 2017; Wilson and Fadel, 2017; Giustino and Maren, 2018; Brandão and Coimbra, 2019; Stubbendorff et al., 2019; Tang et al., 2020). Serotonin and glutamate influence fear memory (Walker and Davis, n.d.; Maren, 1996; Bauer, 2015; Johnson et al., 2015; Bocchio et al., 2016), as does the transcription factor CREB (cyclic AMP response element-binding protein) (Vazdarjanova and McGaugh, 1998; Bocchio et al., 2017; Ressler and Maren, 2019). These important elements have not yet been investigated in $\mathrm{Pcdh} 1 \mathrm{O}^{+/-}$mice. Similarly, structure and function of other brain areas in $\mathrm{Pcdh} 1 \mathrm{O}^{+-}$mice are not well studied. For example, the central amygdala is necessary for fear learning as well (LeDoux et al., 1990; Wilensky et al., 2006).

Interestingly, as with social deficits, $P c d h 10^{+/-}$males preferentially exhibited fear conditioning deficits (Schoch et al., 2017). Both juvenile and adult males displayed deficits in both cued and contextual fear conditioning, whereas females exhibited deficits only as adults in the cued paradigm. This may lend support to the theory that females require higher genetic burden to present ASD-associated phenotypes than males (Jacquemont et al., 2014; Ferri et al., 2018). Although we have determined that $P c d h 10^{+/}$ females have unaltered spine density in the BLA (Schoch, unpublished), we have not investigated NMDAR expression or LA-BLA connectivity. It may be that these or other factors are disrupted in females, or slightly abnormal such that behavioral deficits are only manifest under specific conditions such as in cued fear conditioning, or only in older females, whereas males display deficits at all ages in both memory paradigms. This robust sex difference is interesting and requires further investigation. Exploring these mechanisms may shed light on the male bias of neurodevelopmental disorders.

Like Pcdh10+/- mice, several mouse models associated with ASD exhibit fear conditioning deficits, including CD38, Homer1a, and Scn1a mutants (Han et al., 2012; Banerjee et al., 2016; Kim et al., 2016), as well as a number of others (Markram et al., 2008; Stapley et al., 2013; Howell et al., 2017; Nolan et al., 2017; Fricano-Kugler et al., 2019). Reports of fear conditioning in individuals with ASD have been varied, with some reporting impairments, and some failing to find differences compared to controls (Bernier et al., 2005; Gaigg and Bowler, 2007; Sterling et al., 2013). Recent findings have indicated that amygdala response to fear conditioning is attenuated in individuals with ASD compared with agematched controls (Top Jr. et al., 2016). In addition, changes in amygdala volume, cell size, and responsivity have been reported in individuals with ASD (Bauman and Kemper, 1985; Abell et al., 1999; Baron-Cohen et al., 2000; Critchley et al., 2000; Sparks et al., 2002; Barnea-Goraly et al., 2004; 
Schumann and Amaral, 2006; Conturo et al., 2008; Pinkham et al., 2008; Kohls et al., 2012; Kleinhans et al., 2016), indicating that this brain area is an important player in the neurobiology of ASD. Our present results demonstrating cued and contextual fear conditioning deficits in $\mathrm{Pcdh} 1 \mathrm{O}^{+/-}$males indicate that fear may be a readout of the function of circuits that are impacted in autism.

\section{Acknowledgements}

This work was supported by the National Institutes of Health Grants 1P50MH096891 (Raquel Gur)subproject 6773 (ESB and TA), R01MH080718 (ESB), K01MH119540 (SF), and Pennsylvania Department of Health (SAP \#4100042728) (to Robert Schultz, TA, ESB). TA was supported by the Brush Family Chair of Biology at the University of Pennsylvania. TA and SLF are supported by the Roy J. Carver Charitable Trust at the University of lowa. The content is solely the responsibility of the authors and does not necessarily represent the official views of the National Institute of Mental Health or the National Institutes of Health. The Pennsylvania Department of Health specifically disclaims responsibility for any analyses, interpretations, or conclusions. We would also like to thank the Neural Circuits and Behavior Core at the University of lowa. 


\section{References}

Abell F, Krams M, Ashburner J, Passingham R, Friston K, Frackowiak R, Happé F, Frith C, Frith U (1999) The neuroanatomy of autism: a voxel-based whole brain analysis of structural scans. Neuroreport 10:1647-1651.

Angelakos CC, Tudor JC, Ferri SL, Jongens TA, Abel T (2019) Home-cage hypoactivity in mouse genetic models of autism spectrum disorder. Neurobiol Learn Mem 165.

Aoki E, Kimura R, Suzuki ST, Hirano S (2003) Distribution of OL-protocadherin protein in correlation with specific neural compartments and local circuits in the postnatal mouse brain. Neuroscience 117:593-614.

Banerjee A, Luong JA, Ho A, Saib AO, Ploski JE (2016) Overexpression of Homer1a in the basal and lateral amygdala impairs fear conditioning and induces an autism-like social impairment. Mol Autism 7:16.

Barnea-Goraly N, Kwon H, Menon V, Eliez S, Lotspeich L, Reiss AL (2004) White matter structure in autism: Preliminary evidence from diffusion tensor imaging. Biol Psychiatry 55:323-326.

Baron-Cohen S, Ring HA, Bullmore ET, Wheelwright S, Ashwin C, Williams SC (2000) The amygdala theory of autism. Neurosci Biobehav Rev 24:355-364.

Bauer EP (2015) Serotonin in fear conditioning processes. Behav Brain Res 277:68-77.

Bauman M, Kemper TL (1985) Histoanatomic observations of the brain in early infantile autism. Neurology 35:866-874.

Bernier R, Dawson G, Panagiotides H, Webb S (2005) Individuals with autism spectrum disorder show normal responses to a fear potential startle paradigm. J Autism Dev Disord 35:575-583.

Bocchio M, McHugh SB, Bannerman DM, Sharp T, Capogna M (2016) Serotonin, amygdala and fear: Assembling the puzzle. Front Neural Circuits 10.

Bocchio M, Nabavi S, Capogna M (2017) Synaptic Plasticity, Engrams, and Network Oscillations in Amygdala Circuits for Storage and Retrieval of Emotional Memories. Neuron 94:731-743.

Brandão ML, Coimbra NC (2019) Understanding the role of dopamine in conditioned and unconditioned fear. Rev Neurosci 30:325-337.

Bucan M et al. (2009) Genome-wide analyses of exonic copy number variants in a family-based study point to novel autism susceptibility genes. PLoS Genet 5:e1000536.

Campeau S, Miserendino MJD, Davis M (1992) Intra-Amygdala Infusion of the N-Methyl-D-Aspartate Receptor Antagonist AP5 Blocks Acquisition but Not Expression of Fear-Potentiated Startle to an Auditory Conditioned Stimulus. Behav Neurosci 106:569-574.

Clark RE, Squire LR (1998) Classical conditioning and brain systems: The role of awareness. Science (80- ) 280:77-81.

Conturo TE, Williams DL, Smith CD, Gultepe E, Akbudak E, Minshew NJ (2008) Neuronal fiber pathway abnormalities in autism: An initial MRI diffusion tensor tracking study of hippocampo-fusiform and amygdalo-fusiform pathways. In: Journal of the International Neuropsychological Society, pp 933946. J Int Neuropsychol Soc.

Critchley HD, Daly EM, Bullmore ET, Williams SCR, Van Amelsvoort T, Robertson DM, Rowe A, Phillips M, 
McAlonan G, Howlin P, Murphy DGM (2000) The functional neuroanatomy of social behaviour. Brain 123:2203-2212.

de la Mora MP, Gallegos-Cari A, Arizmendi-García Y, Marcellino D, Fuxe K (2010) Role of dopamine receptor mechanisms in the amygdaloid modulation of fear and anxiety: Structural and functional analysis. Prog Neurobiol 90:198-216.

de Oliveira AR, Reimer AE, Reis FMCV, Brandão ML (2017) Dopamine D2-like receptors modulate freezing response, but not the activation of HPA axis, during the expression of conditioned fear. Exp Brain Res 235:429-436.

Ferri SL, Abel T, Brodkin ES (2018) Sex Differences in Autism Spectrum Disorder: a Review. Curr Psychiatry Rep 20.

Ferri SL, Kreibich A, Torre M, Piccoli CT, Pallathra A, Dow HC, Li H, Gur R, Abel T, Brodkin ES (2015) Activation of basolateral amygdala in juvenile $\mathrm{C} 57 \mathrm{BI} / 6 \mathrm{~J}$ mice during social approach.

Fricano-Kugler C, Gordon A, Shin G, Gao K, Nguyen J, Berg J, Starks M, Geschwind DH (2019) CYFIP1 overexpression increases fear response in mice but does not affect social or repetitive behavioral phenotypes. Mol Autism 10.

Gaigg SB, Bowler DM (2007) Differential fear conditioning in Asperger's syndrome: Implications for an amygdala theory of autism. Neuropsychologia 45:2125-2134.

Giustino TF, Maren S (2018) Noradrenergic modulation of fear conditioning and extinction. Front Behav Neurosci 12.

Goosens KA, Maren S (2001) Contextual and auditory fear conditioning are mediated by the lateral, basal, and central amygdaloid nuclei in rats. Learn Mem 8:148-155.

Han S, Tai C, Westenbroek RE, Yu FH, Cheah CS, Potter GB, Rubenstein JL, Scheuer T, De La Iglesia HO, Catterall WA (2012) Autistic-like behaviour in Scn1a +- mice and rescue by enhanced GABAmediated neurotransmission. Nature 489:385-390.

Harris KM (1999) Structure, development, and plasticity of dendritic spines. Curr Opin Neurobiol 9:343348.

Heath FC, Jurkus R, Bast T, Pezze MA, Lee JLC, Voigt JP, Stevenson CW (2015) Dopamine D1-like receptor signalling in the hippocampus and amygdala modulates the acquisition of contextual fear conditioning. Psychopharmacology (Berl) 232:2619-2629.

Hirano S, Yan Q, Suzuki ST (1999) Expression of a novel protocadherin, OL-protocadherin, in a subset of functional systems of the developing mouse brain. J Neurosci 19:995-1005.

Howell CJ, Sceniak MP, Lang M, Krakowiecki W, Abouelsoud FE, Lad SU, Yu H, Katz DM (2017) Activation of the medial prefrontal cortex reverses cognitive and respiratory symptoms in a mouse model of RETT syndrome. eNeuro 4.

Jacquemont S, Coe BP, Hersch M, Duyzend MH, Krumm N, Bergmann S, Beckmann JS, Rosenfeld JA, Eichler EE (2014) A higher mutational burden in females supports a "female protective model" in neurodevelopmental disorders. Am J Hum Genet 94:415-425.

Johnson PL, Molosh A, Fitz SD, Arendt D, Deehan GA, Federici LM, Bernabe C, Engleman EA, Rodd ZA, Lowry CA, Shekhar A (2015) Pharmacological depletion of serotonin in the basolateral amygdala 
complex reduces anxiety and disrupts fear conditioning. Pharmacol Biochem Behav 138:174-179.

Kim S-Y, Yasuda S, Tanaka H, Yamagata K, Kim H (2011) Non-clustered protocadherin. Cell Adh Migr 5:97-105.

Kim S, Kim TH, Lee HR, Jang EH, Ryu HH, Kang M, Rah SY, Yoo J, Lee B, Kim JI, Lim CS, Kim SJ, Kim UH, Lee YS, Kaang BK (2016) Impaired learning and memory in CD38 null mutant mice. Mol Brain 9:16.

Kleinhans NM, Richards T, Greenson J, Dawson G, Aylward E (2016) Altered Dynamics of the fMRI Response to Faces in Individuals with Autism. J Autism Dev Disord 46:232-241.

Kohls G, Chevallier C, Troiani V, Schultz RT (2012) Social “wanting” dysfunction in autism: neurobiological underpinnings and treatment implications. J Neurodev Disord 4:10.

Kwon O Bin, Lee JH, Kim HJ, Lee S, Lee S, Jeong MJ, Kim SJ, Jo HJ, Ko B, Chang S, Park SK, Choi YB, Bailey $\mathrm{CH}$, Kandel ER, Kim JH (2015) Dopamine Regulation of Amygdala Inhibitory Circuits for Expression of Learned Fear. Neuron 88:378-389.

LeDoux JE, Cicchetti P, Xagoraris A, Romanski LM (1990) The lateral amygdaloid nucleus: Sensory interface of the amygdala in fear conditioning. J Neurosci 10:1062-1069.

Maren S (1996) Synaptic transmission and plasticity in the amygdala: An emerging physiology of fear conditioning circuits. Mol Neurobiol 13:1-22.

Markram K, Rinaldi T, Mendola D La, Sandi C, Markram H (2008) Abnormal Fear Conditioning and Amygdala Processing in an Animal Model of Autism. Neuropsychopharmacology 33:901-912.

Morrow EM et al. (2008) Identifying autism loci and genes by tracing recent shared ancestry. Science 321:218-223.

Nabavi S, Fox R, Proulx CD, Lin JY, Tsien RY, Malinow R (2014) Engineering a memory with LTD and LTP. Nature 511:348-352.

Nakao S, Platek A, Hirano S, Takeichi M (2008) Contact-dependent promotion of cell migration by the OL-protocadherin-Nap1 interaction. J Cell Biol 182:395-410.

Nolan SO, Reynolds CD, Smith GD, Holley AJ, Escobar B, Chandler MA, Volquardsen M, Jefferson T, Pandian A, Smith T, Huebschman J, Lugo JN (2017) Deletion of Fmr1 results in sex-specific changes in behavior. Brain Behav 7.

Pinkham AE, Hopfinger JB, Pelphrey KA, Piven J, Penn DL (2008) Neural bases for impaired social cognition in schizophrenia and autism spectrum disorders. Schizophr Res 99:164-175.

Popescu AT, Popa D, Paré D (2009) Coherent gamma oscillations couple the amygdala and striatum during learning. Nat Neurosci 12:801-807.

Ressler RL, Maren S (2019) Synaptic encoding of fear memories in the amygdala. Curr Opin Neurobiol 54:54-59.

Rogan MT, Staubli U V., LeDoux JE (1997) Fear conditioning induces associative long-term potentiation in the amygdala. Nature 390:604-607.

Schoch H et al. (2017) Sociability Deficits and Altered Amygdala Circuits in Mice Lacking Pcdh10, an Autism Associated Gene. Biol Psychiatry 81:193-202. 
Schumann CM, Amaral DG (2006) Stereological analysis of amygdala neuron number in autism. J Neurosci 26:7674-7679.

Sparks BF, Friedman SD, Shaw DW, Aylward EH, Echelard D, Artru AA, Maravilla KR, Giedd JN, Munson J, Dawson G, Dager SR (2002) Brain structural abnormalities in young children with autism spectrum disorder. Neurology 59:184-192.

Stapley NW, Guariglia SR, Chadman KK (2013) Cued and contextual fear conditioning in BTBR mice is improved with training or atomoxetine. Neurosci Lett 549:120-124.

Sterling L, Munson J, Estes A, Murias M, Webb SJ, King B, Dawson G (2013) Fear-potentiated startle response is unrelated to social or emotional functioning in adolescents with autism spectrum disorders. Autism Res 6:320-331.

Stubbendorff C, Hale E, Cassaday HJ, Bast T, Stevenson CW (2019) Dopamine D1-like receptors in the dorsomedial prefrontal cortex regulate contextual fear conditioning. Psychopharmacology (Berl) 236:1771-1782.

Stujenske JM, Likhtik E, Topiwala MA, Gordon JA (2014) Fear and safety engage competing patterns of theta-gamma coupling in the basolateral amygdala. Neuron 83:919-933.

Tang W, Kochubey O, Kintscher M, Schneggenburger R (2020) A VTA to basal amygdala dopamine projection contributes to signal salient somatosensory events during fear learning. J Neurosci:JNRM-1796-19.

Taylor SC, Ferri SL, Grewal M, Smernoff Z, Bucan M, Weiner JA, Abel T, Brodkin ES (2020) The Role of Synaptic Cell Adhesion Molecules and Associated Scaffolding Proteins in Social Affiliative Behaviors. Biol Psychiatry.

Top Jr. DN, Stephenson KG, Doxey CR, Crowley MJ, Kirwan CB, South M (2016) Atypical Amygdala Response to Fear Conditioning in Autism Spectrum Disorder. Biol Psychiatry Cogn Neurosci Neuroimaging 1:308-315.

Tsai PT, Hull C, Chu Y, Greene-Colozzi E, Sadowski AR, Leech JM, Steinberg J, Crawley JN, Regehr WG, Sahin M (2012) Autistic-like behaviour and cerebellar dysfunction in Purkinje cell Tsc1 mutant mice. Nature 488:647-651.

Uemura M, Nakao S, Suzuki ST, Takeichi M, Hirano S (2007) OL-protocadherin is essential for growth of striatal axons and thalamocortical projections. Nat Neurosci 10:1151-1159.

Vazdarjanova A, McGaugh JL (1998) Basolateral amygdala is not critical for cognitive memory of contextual fear conditioning. Proc Natl Acad Sci U S A 95:15003-15007.

Walker DL, Davis M (n.d.) The role of amygdala glutamate receptors in fear learning, fear-potentiated startle, and extinction.

Wilensky AE, Schafe GE, Kristensen MP, LeDoux JE (2006) Rethinking the fear circuit: The central nucleus of the amygdala is required for the acquisition, consolidation, and expression of pavlovian fear conditioning. J Neurosci 26:12387-12396.

Wilson MA, Fadel JR (2017) Cholinergic regulation of fear learning and extinction. J Neurosci Res 95:836852. 